\title{
Does mentoring for young women introduce a feminist approach? A scoping review
}

\author{
Mireia Foradada Villar \\ Universitat de Lleida. Spain. \\ mireia.foradada.villar@gmail.com \\ Josefina Sala Roca \\ Universitat Autònoma de Barcelona. Spain. \\ fina.sala@uab.cat
}

Received: 8/8/2019

Accepted: 3/2/2020

Published: 20/7/2020

\begin{abstract}
Although mentoring for young people at risk of social exclusion is a widespread educational intervention strategy, little research has been conducted on mentoring for young women aimed at eradicating gender inequalities. This article examines the existing scientific literature on mentoring for young women by means of a scoping review. A total of 1,256 studies were compiled from six specialized databases. Of these, 21 papers were selected and analyzed in depth, three of which are defined by the authors as feminist mentoring (Femtoring). Our analysis served to identify the main characteristics of mentoring programs for young women and the implications of the feminist perspective at the socio-educational level. Furthermore, reflective tools are provided on the empowerment processes stemming from a feminist approach to mentoring programs.
\end{abstract}

Keywords: mentoring; young women; review; scoping review; feminist perspective

Resum. La mentoria per a dones joves inclou la perspectiva feminista? Una revisió sistemàtica exploratòria

Tot i que la mentoria per a joves en risc d'exclusió social és una estratègia d'intervenció educativa molt estesa, poc s'ha investigat sobre la mentoria per a dones joves que persegueix l'erradicació de les desigualtats de gènere. A través d'una revisió sistemàtica exploratòria s'ha examinat la literatura existent sobre mentoria per a dones joves. S'han recopilat 1.256 estudis de 6 bases de dades especialitzades, dels quals s'han seleccionat 21 treballs que han estat analitzats en profunditat, tres dels quals s'autodefineixen com a mentories feministes (femtoring). L'anàlisi a permès d'identificar les principals característiques dels programes de mentoria per a dones joves i les implicacions de la perspectiva feminista en l'àmbit socioeducatiu. Tanmateix, s'ofereixen les eines reflexives sobre els processos d'apoderament que es desprenen dels programes sobre mentoria d'aproximació feminista.

Paraules clau: mentoria; dones joves; revisió; revisió sistemàtica exploratòria; perspectiva feminista 
Resumen. ¿La mentoría para mujeres jóvenes introduce la perspectiva feminista? Una revisión sistemática exploratoria

Aunque la mentoría para jóvenes en riesgo de exclusión social es una estrategia de intervención educativa muy extendida, poco se ha investigado sobre la mentoría para mujeres jóvenes que persigue la erradicación de las desigualdades de género. A través de una revisión sistemática exploratoria se ha examinado la literatura científica existente sobre mentoría para mujeres jóvenes. Se recopilaron 1.256 estudios de 6 bases de datos especializadas, de los que se seleccionaron 21 trabajos que fueron analizados en profundidad, tres de los cuales se autodefinen como mentorías feministas (femtoring). El análisis ha permitido identificar las principales características de los programas de mentoría para mujeres jóvenes y las implicaciones de la perspectiva feminista en el ámbito socioeducativo. Asimismo, se ofrecen herramientas reflexivas sobre los procesos de empoderamiento que se desprenden de los programas sobre mentoría de aproximación feminista.

Palabras clave: mentoría; mujeres jóvenes; revisión; revisión sistemática exploratoria; perspectiva feminista

\author{
Summary \\ 1. Introduction 4. Future directions: Implications for \\ 2. Methodology research and socio-educational practice \\ 3. Results Bibliographical references
}

\title{
1. Introduction
}

Gender inequality affects the lives of adolescent girls and young women at the professional, educational and training levels, as well as in their intimate relationships and sexuality and in their visualization and representation in public spaces. To prevent it, various types of intervention programs have been developed, including mentoring programs. This article presents a review of the scientific articles that have analyzed mentoring programs aimed at eradicating the inequalities suffered by young people in different spheres.

The fact of being born a woman places any woman, regardless of age, in a position of normalized gender inequality (Segato, 2003; World Health Organization, 2017). Women face systemic inequality. One of the most obvious areas of gender inequality is in the professional arena. The Observatori iQ (2016) points out that young women with a medium or higher-level education have more precarious working conditions than men of the same age, despite having the same level of education. In addition, their income is always lower (Eurostat, 2017), and they are also at a higher risk of poverty than men of the same age (Eurostat, 2018). Gender discrimination in the workplace is so ingrained that it even persists in areas such as science. Phipps (2007) examined the male culture at university, and concluded that there were mechanisms in place to expel young women from certain scientific-academic levels, as well as institu- 
tional resistances by the university to advance policies of equality (Verge, Ferrer-Fons \& González, 2018).

No less relevant and concerning is the sexual violence suffered by a large majority of young women at some point in their lives (Eurostat, 2016; Observatorio Noctámbul@s, 2017). The study The state of girl's rights in the UK(2016) found that one in five girls interviewed $(22 \%)$ had experienced some type of sexual violence (touching, assault or rape) in the vicinity of a center of education. The study concluded that "(...) For girls, blatant rights violations such as sexual violence are underpinned by a reality too often defined by gendered expectations and everyday harassment" (2006, p. 14). Considering the above, the violence suffered by young women should be analyzed within the conceptual framework of gender violence, even if these girls may also be minors.

In this context, mentoring for young people emerges as a preventive strategy to counter the impact of factors associated with environments of exclusion and vulnerability, and also as an empowerment strategy that fosters autonomy and increases social capital (Rhodes, 2005; DuBois \& Karcher, 2013; Clutterbuck, Poulsen \& Kochan, 2012). Mentoring programs for young people mostly focus on the development of instrumental competencies - necessary for autonomy and/or the workplace - and emotional competencies - necessary for personal well-being, improving self-esteem and healthy social relationships (Liang, Bogat \& Duffy, 2013).

Femtoring, notwithstanding, has emerged as a model of feminist diversity mentoring for adolescent and young women (Benishek, Bieschke, Park \& Slattery, 2004; Fassinger \& Hensler-McGinnis, 2005; Bay-cheng, Lewis, Stewart \& Malley, 2006). This form of mentoring seeks to introduce gender competencies and the feminist perspective, in different spheres to provide a more holistic response to the inequalities faced by young women. In addition, mentoring programs directly or indirectly seek to increase social capital linked to the interpersonal support of young women (Hernandez et al., 2017), since it is a protective factor in gender violence contexts (Kirst, Lazgare, Zhang \& O'Campo, 2015). Moreover, this social capital provides instrumental, informational, emotional and even financial support.

From the point of view of diversity, Sanghera \& Thapar-Bjorkert (2017) contradict the assumption that women's social capital is less significant than men's because women's social network is smaller and more informal. Communication technologies allow girls and daughters of immigrants to establish transnational bridges that prevent the social capital depletion traditionally attributed to immigration processes. Thus, their study found that girls have the ability to mobilize faith-based capital to fight against gender inequality and Islamophobia. These contributions suggest the need to analyze the different fields of socio-educational intervention with young people, such as mentoring, so as not to reproduce these inequality dynamics through professional intervention.

Considering the above, the aim of this research is to examine whether mentoring projects aimed at girls at risk of social exclusion include objectives 
that pursue the empowerment of young women and/or the eradication of gender-based violence at young ages.

\section{Methodology}

The Scoping Review methodology was chosen to carry out the study (Arksey \& O’Malley, 2005). It was performed using seven search engines: Dialnet, JSTOR, Web of Science, Scopus, ProQuest and GoogleScholar. The terms used in the search stemmed from the need to know whether the mentoring programs ("mentor*program" or "mentor*") included the feminist perspective ("gender" or "gender-based" or "feminist") when they were aimed at young women ("young women" or "female adolescent"). We reviewed those documents that included these descriptors in the title, abstract and/or keywords.

The review included original scientific articles, research reports and doctoral theses on mentoring for young women published between 2000 and 2018 . Only those with a sample comprising young women aged 16 to 30 were included. And only works published in English, Spanish or Catalan were reviewed, due to the researcher's language capabilities.

Works whose object of study was individual counselling were excluded, as these should be considered socio-educational interventions with different purposes and methodologies. Finally, those works whose sample consisted of both young women and young men were also excluded, due to the interest of this scientific article lying in determining the areas and topics of intervention in mentoring for girls.

From the search, 1,156 references were found. Mendeley software was used to detect duplicate items. In a first phase of screening and reviewing the title and abstract, 1,012 were excluded. Based on a reading of the complete text of the 144 remaining articles, 20 works were selected that meet all the established selection criteria (Fig. 1). Finally, one last relevant work was included in this study on mentoring for young women: A multicultural feminist model of mentoring by Benishek et al. (2004). This article makes a theoretical and reflective contribution to mentoring projects for young women from the intercultural and gender perspective, which means that we based our work on a theoretical study that has contributed at the epistemological level to nourishing the data analysis that would later be conducted.

Finally, the main features of mentoring programs and research presented as results have been identified deductively. Consequently, these were compiled taking into account socio-educational and feminist literature on mentoring. 
Figure 1. Overview of study selection process

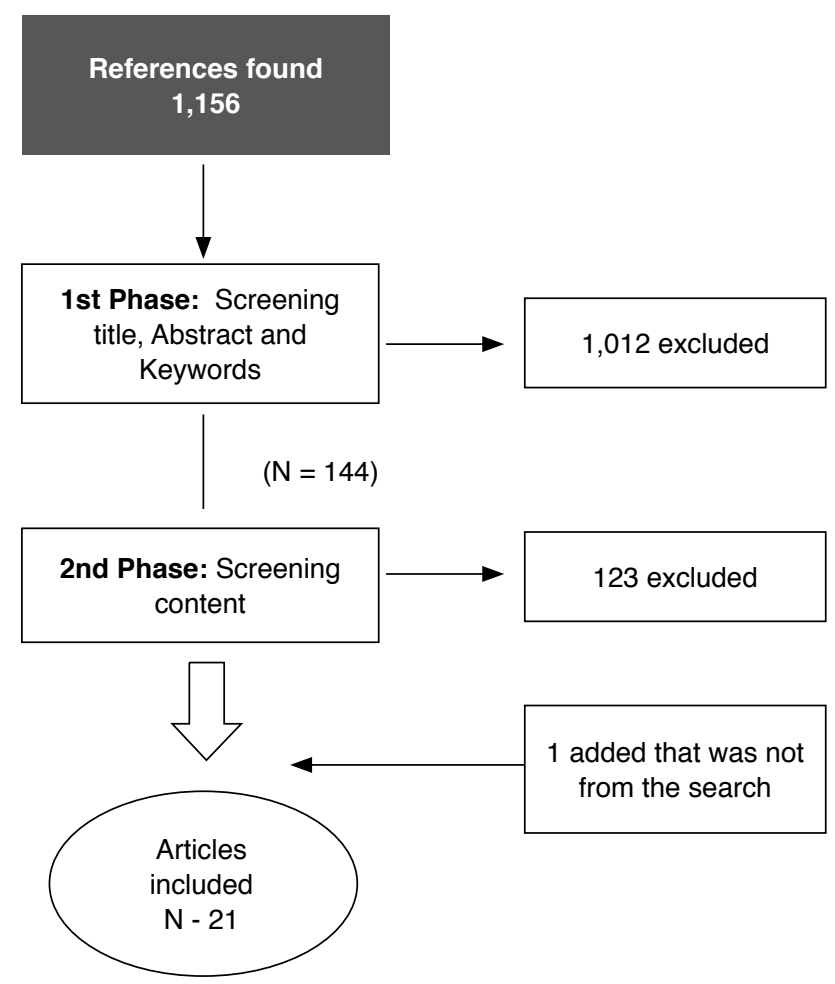

Source: own elaboration.

Table 1. Overview of the reviewed works on mentoring for young women

\begin{tabular}{llll}
\hline \multicolumn{1}{c}{ Reference } & Methodology & \multicolumn{1}{c}{ Subject matter and Aims of the programs } & $\begin{array}{c}\text { Type } \\
\text { of mentoring }\end{array}$ \\
\hline 1. Mezey et al. (2015) & Mixed & $\begin{array}{l}\text { Prevent pregnancy among adolescents and young } \\
\text { women in and leaving care. }\end{array}$ & $\begin{array}{l}\text { Group (Peer- } \\
\text { mentoring) }\end{array}$ \\
$\begin{array}{llll}\text { 2. Greeson \& Bowen } \\
\text { (2008) }\end{array}$ & Qualitative & $\begin{array}{l}\text { Determine the impact of natural mentoring in the } \\
\text { case of racialized young women in and leaving } \\
\text { care. }\end{array}$ & $\begin{array}{l}\text { Natural men- } \\
\text { toring }\end{array}$ \\
$\begin{array}{l}\text { 3. Lindsay-Dennis, } \\
\text { Cummings, \& McClen- } \\
\text { don (2011) }\end{array}$ & $\begin{array}{l}\text { Qualitative } \\
\text { 4. Tortolani (2011) }\end{array}$ & $\begin{array}{l}\text { Understand the experience of (adult) women Afri- } \\
\text { can American mentors who participated in a men- }\end{array}$ & $\begin{array}{l}\text { One-on-one } \\
\text { and group }\end{array}$ \\
& Mixed & $\begin{array}{l}\text { Exing program focused on racial diversity. } \\
\text { areas who participate in an action-research pro- } \\
\text { gram. }\end{array}$ & $\begin{array}{l}\text { Group } \\
\text { mentoring }\end{array}$ \\
\hline
\end{tabular}




\begin{tabular}{|c|c|c|c|}
\hline Reference & Methodology & Subject matter and Aims of the programs & $\begin{array}{l}\text { Type of } \\
\text { mentoring }\end{array}$ \\
\hline $\begin{array}{l}\text { 5. Newton, Harris, } \\
\text { Hubbard \& Craig } \\
(2017)\end{array}$ & Qualitative & $\begin{array}{l}\text { Examine the impact of the mentoring program on } \\
\text { girls in care during their transition to adult life. }\end{array}$ & One-on-one \\
\hline $\begin{array}{l}\text { 6. Hernandez et al. } \\
\text { (2017) }\end{array}$ & Quantitative & $\begin{array}{l}\text { Examine the benefits of a new informal mentoring } \\
\text { program, which aims to: 1) Support and develop } \\
\text { the scientific identity of its female students; } 2 \text { ) Moti- } \\
\text { vate their scientific interest in studying the Earth } \\
\text { and environmental sciences; 3) Attain higher num- } \\
\text { bers of women students doing a science degree. }\end{array}$ & Mixed \\
\hline $\begin{array}{l}\text { 7. Levine, Mechaber, } \\
\text { Reddy, Cayea \& Har- } \\
\text { rison (2013) }\end{array}$ & Qualitative & $\begin{array}{l}\text { Explore the role played by gender roles in men- } \\
\text { toring relationships, on a mentoring program for } \\
\text { female medical students. }\end{array}$ & One-on-one \\
\hline $\begin{array}{l}\text { 8. Leck, Elliott \& Rock- } \\
\text { well (2012) }\end{array}$ & Qualitative & $\begin{array}{l}\text { Determine the overall effectiveness of a pilot } \\
\text { e-mentoring program aimed at providing psycho- } \\
\text { social support for young women in the develop- } \\
\text { ment of their professional career and to generate a } \\
\text { virtual environment of trust for them. }\end{array}$ & One-on-one \\
\hline 9. Brown (2006) & Qualitative & $\begin{array}{l}\text { Identify forms of empowerment among women who } \\
\text { participated in the CAG mentoring program (Cel- } \\
\text { ebrating All Girls). }\end{array}$ & $\begin{array}{l}\text { Group } \\
\text { (Femtoring) }\end{array}$ \\
\hline $\begin{array}{l}\text { 10. Liang, Tracy, Taylor } \\
\& \text { Williams (2002) }\end{array}$ & Quantitative & $\begin{array}{l}\text { Use the RHI-M index to explore the direct and } \\
\text { moderate effects of a high-quality mentoring rela- } \\
\text { tionship. }\end{array}$ & One-on-one \\
\hline $\begin{array}{l}\text { 11. Kalpazidou } \\
\text { Schmidt \& Faber } \\
\text { (2016) }\end{array}$ & Qualitative & $\begin{array}{l}\text { Describe and analyze the benefits of mentoring on } \\
\text { science degrees in postdoc women and also for } \\
\text { the university institution. }\end{array}$ & One-on-one \\
\hline $\begin{array}{l}\text { 12. Bankar et al. } \\
\text { (2018) }\end{array}$ & Qualitative & $\begin{array}{l}\text { Identify the strategies that women mentors follow to } \\
\text { change social gender norms through a sports pro- } \\
\text { gram for teenage girls in the suburbs of Mumbai. }\end{array}$ & Mixed \\
\hline 13. Falb et al. (2016) & Mixed & $\begin{array}{l}\text { The aim of this transnational study is to understand } \\
\text { the viability, acceptance and effectiveness of the } \\
\text { COMPASS program. This program aims to prevent } \\
\text { adolescent girls from suffering gender-based vio- } \\
\text { lence in contexts of humanitarian aid. }\end{array}$ & $\begin{array}{l}\text { Group } \\
\text { mentoring }\end{array}$ \\
\hline $\begin{array}{l}\text { 14. Larsson, Petters- } \\
\text { son, Skoog \& Eriksson } \\
\text { (2016) }\end{array}$ & Mixed & $\begin{array}{l}\text { Develop more specific knowledge regarding the } \\
\text { effects of mentoring relationships in girls who live } \\
\text { with a mental illness. }\end{array}$ & One-on-one \\
\hline $\begin{array}{l}\text { 15. McGill, Adler-Bae- } \\
\text { der, Sollie, \& Kerpel- } \\
\text { man (2015) }\end{array}$ & Qualitative & $\begin{array}{l}\text { Investigate the emerging experiences of mentors, } \\
\text { exploring both the positive potential and the nega- } \\
\text { tive results of mentoring experiences. }\end{array}$ & Mixed \\
\hline $\begin{array}{l}\text { 16. Larsson, Petters- } \\
\text { son, Eriksson \& Skoog } \\
\text { (2016) }\end{array}$ & Qualitative & $\begin{array}{l}\text { Examine the motives of mentors participating vol- } \\
\text { untarily in a mentoring program for young women, } \\
\text { and learn how organizations can facilitate these } \\
\text { expectations to engage and retain these young } \\
\text { women in their projects. }\end{array}$ & \\
\hline $\begin{array}{l}\text { 17. Klaw, Rhodes \& } \\
\text { Fitzgerald (2003) }\end{array}$ & Quantitative & $\begin{array}{l}\text { Examine the duration, characteristics and effects of } \\
\text { the mentoring relationship during the first two years } \\
\text { after giving birth. Also, note the similarities and dif- } \\
\text { ferences between the support of the mentor and } \\
\text { the maternal support adolescents received. }\end{array}$ & $\begin{array}{l}\text { Natural } \\
\text { mentoring }\end{array}$ \\
\hline
\end{tabular}




\begin{tabular}{llll}
\hline \multicolumn{1}{c}{ Reference } & Methodology & \multicolumn{1}{c}{ Subject matter and Aims of the programs } & $\begin{array}{c}\text { Type of } \\
\text { mentoring }\end{array}$ \\
\hline $\begin{array}{l}\text { 18. Bay-Cheng, Lewis, } \\
\text { Stewart, \& Malley } \\
\text { (2006) }\end{array}$ & Qualitative & $\begin{array}{l}\text { Explore the meanings and messages about sexual- } \\
\text { ity passed on to girls in mentoring relationships. }\end{array}$ & $\begin{array}{l}\text { Group } \\
\text { mentoring }\end{array}$ \\
$\begin{array}{l}\text { 19. Spencer \& Liang } \\
\text { (2009) }\end{array}$ & Qualitative & $\begin{array}{l}\text { Examine the relationship established on a men- } \\
\text { toring program between adult women and girls, } \\
\text { understand their experiences during their participa- } \\
\text { tion in it and, specifically, provide new scientific } \\
\text { data on non-mixed mentoring relationships (among } \\
\text { women). }\end{array}$ & One-on-one \\
$\begin{array}{l}\text { 20. Bogat, Liang \& } \\
\text { Rigol-Dahn (2008) }\end{array}$ & Qualitative & $\begin{array}{l}\text { Identify and describe the phases that occur on a } \\
\text { mentoring program for pregnant teenage girls. }\end{array}$ & One-on-one \\
$\begin{array}{llll}\text { 21. Benishek, Biesch- } \\
\text { ke, Park \& Slattery } \\
\text { (2004) }\end{array}$ & Qualitative & $\begin{array}{l}\text { Theoretical article reflecting on new feminist and } \\
\text { gender dimensions that occur in mentoring rela- }\end{array}$ & - \\
\hline
\end{tabular}

Source: own elaboration.

\section{Results}

The contents of the 21 selected studies were analyzed considering the main features characterizing the programs and research on mentoring for girls at risk of social exclusion on the one hand, and their content on the other.

\subsection{Program description}

A first aspect that should be highlighted in this section is the subject matter of the programs analyzed. A theme common to all programs is the gender discrimination suffered by young women, which is incorporated into the programs in the following way: raising awareness of women's rights and their participation (in 8 studies); preventing teenage pregnancies or support for teenage mothers (3); preventing racial and ethnic discrimination and making diversity visible (7); providing support for young people during their transition to adult life (1); eradicating and preventing gender violence, the right to sexual education (3); support for young girls with mental illness (2); empowering girls to decide about their lives (15); and constructing social capital to facilitate social participation by women and avoid their social isolation (12).

A second aspect of interest is the space in which the mentoring intervention takes place. The mentoring programs studied were carried out in everyday contexts for young women, where dynamics of gender inequality were identified. Consequently, the programs are supported by data that indicate how young women do not participate in equal conditions in these spaces, and therefore there is no real equality of opportunities for them. Four main areas of intervention were identified: secondary school (1), university (3), the workplace (1) and the community context where they live (16).

A third descriptive aspect of interest for this work is the mentoring model adopted by the mentors to relate to the girls. In 11 cases, the mentoring pro- 
jects were one-on-one, that is, a model based on mentoring couples in which there is a mentor for each mentee. Within this model, two one-on-one submodels were identified in the programs analyzed: on the one hand, natural mentoring and on the other e-mentoring. Another model to be identified is the group mentoring model (4). In this type of mentoring, one or more mentors accompany a group of girls using group participation techniques and conducting participatory workshops. Finally, another identified model is what we have called the mixed mentoring model, which was found in 5 of the 21 studies reviewed. This model combines one-on-one mentoring with group mentoring to work on educational objectives at different psychosocial and competency levels.

In short, we can state that the one-on-one model is most used in mentoring programs for girls, although group mentoring is no less important, and was found in 9 of the studies, either alone or within the mixed model.

A final aspect of this block is the research methodology for evaluating mentoring programs. Although evaluating mentoring programs is a complex issue, the studies analyzed here used a qualitative, quantitative or mixed methodology to evaluate their results. Of the works consulted, only three followed a strictly quantitative methodology, because they included samples of over 100 people. On the other hand, four of the studies followed a mixed methodology. One of the studies concluded that as a result of the qualitative methodology, more explanatory data had been collected to understand the individual processes that occurred in mentoring relationships (study 1). The rest of the studies (14) followed a qualitative methodology. These focused primarily on analyzing the processes of the mentoring relationship to determine its effects on the participants, and were interested in the relationship at the different stages of the mentoring process, both individually and as a group.

\subsection{Program content}

Three basic socio-educational goals were identified in the analyzed programs. First, mentoring to eradicate social inequality for women, that is, the gender inequality that occurs in their different social spheres. Second, mentoring that intervenes in relation to gender and racial inequality. And, third, mentoring that pursues the empowerment of young women.

\subsubsection{The social inequality experienced by young women}

Being a woman/adolescent girl is the central element and backbone of all of the mentoring studies analyzed, which are based on the same shared vision: young women suffer from structural gender discrimination in society and therefore have fewer rights and opportunities. Thus, the areas of intervention included in the programs are directly or indirectly related to this inequality suffered by women. Those programs where the feminist approach is more explicit because it understands the gender vector as the axis of inequality introduce several of the themes: raising awareness of the discrimination suf- 
fered by women in different areas of society and the importance of their social participation (studies 4, 7, 8, 11, 12 and 13), providing support for women who have become mothers at a very young age (studies 1, 18 and 21), preventing gender violence and the right to sex education (studies 1, 13 and 14), and empowerment, which appears in 15 of the 22 studies reviewed (Table 1). Those studies that, aside from working on individual empowerment, also combine more than one of these themes, approach a more systemic intervention at the socio-educational level (studies 3 and 4) or the proposal of "conscious Femtoring" by Brown (2006) (study 9). These works can, at the same time, be identified as addressing feminist mentoring or adopting an intersectional feminist approach, as they themselves state, since they take into account vectors of social exclusion such as gender, race and social class, as well as positions of power or more peripheral positions in the mentoring relationship.

\subsubsection{Race and gender}

Another aspect linked to the gender inequality experienced by young women, and which appears as a relevant element, is racism as a vector of vulnerability alongside gender (in seven studies). These programs have been classified into three types, according to the degree of intensity and awareness with which they systemically approach this inequality at the theoretical level, and through the intervention described in the studies.

The first type of program is characterized by understanding racial and gender discrimination as the main themes that must underpin mentoring. These programs aim to break with the stigma suffered by racialized women, mainly young black women, and positively redefine blackness through (positive) reference women and people. In addition, they aim to act in a non-revictimizing manner, as well as promoting social cohesion and sisterhood among mentees (studies 3 and 4). In these cases, the most widely used mentoring model is the mixed model, because the group-space becomes a strategy for sharing individual discomfort and working with the agency capacity of (and among) young people.

A second type of program recognizes the existence of this racial discrimination at the theoretical level, and consequently understands racism as a vector of social vulnerability among the girls of this group. However, in these cases mentoring actions pursue more positive reinforcement of the girl's identity at the individual level (study 2). One of the most important aims is to achieve a real bond between mentor and mentee and promote conditions of equality through these accompaniments in the context/institution where the mentoring project takes place (study 10).

The third type of program identifies the group of racialized young people as a group at risk of social exclusion. These studies do not reflect any specific intervention in this inequality, but rather this (one-on-one) mentoring pursues instrumental or emotional skills objectives in mentoring programs for young people, regardless of the racial and ethnic issue (studies 17, 19 and 20). 


\subsubsection{Inequality and empowerment}

Empowerment is an explicit goal in the vast majority of the studies analyzed, specifically in $71.4 \%$, and these infer that both the mentee and the mentor experience it. Within the framework of these programs, empowerment is understood as increasing the social, political and economic rights of young women. As in the previous section, however, the form and strategy used to foster it differ between programs. On the one hand, programs have been found that pursue empowerment through more instrumental mentoring (studies 8, $11,17,19)$, as happens in programs related to the educational, university or professional field. On the other hand, mentoring has been found that tends to do more emotional (study 5) or psychosocial (studies 1 and 14) work and/ or work on social and personal emancipation (study 11). That said, we can state that the vast majority of mentoring programs found combine both dimensions (instrumental and socio-emotional).

To determine which dimensions are related to empowerment, we have identified four subdimensions of this:

- Identity and agency capacity. This dimension appears in the programs when mentoring aims for young people in certain groups to detach themselves from the negative social image that befalls them due to stigma or a social barrier, as would be the case of the aforementioned mentoring aimed at prevention in the group of racialized girls. Or mentoring in the university field, where it seeks to reinforce a professional identity so that students can participate in and follow their scientific career (studies 6, 7 and 11). In these cases, work on identity and agency capacity is central in order to promote a process of positive resignification of one's own identities.

- Space for security and well-being. Mentoring is not only conceived as a mere relationship, but also as a "space-time" of empowerment, security and well-being (studies 12 and 13). In the first place, because mentoring relationships between women make it possible to have a relationship between equals with trust and mutual support, in a situated way and in a determined context with concrete meanings. This type of relationship affords the opportunity to share experiences and concerns with another person who is also willing to live in that space-time. Moreover, mentoring facilitates the social participation of young women where the different social, cultural and gender practices pertaining to girls have a place (studies 12 and 13), and its internal dynamics contribute to reducing the stress generated by the social unrest of the mentored environment (studies 5 and 19), and breaking the gender barriers that make this difficult (study 12).

- Psycho-social elements of empowerment. One of the challenges in empowering women is improving their self-esteem. In fact, study 2 reflects that, despite the girls having a positive one-on-one reference, there was not much improvement in self-esteem and consequently in terms of empowerment either. For this reason, the aforementioned study emphasizes the need for specific intervention with a view to improving girls' and young 
women's self-esteem through mentoring. In regard to this, $43 \%$ of the analyzed works focus on this dimension and reflect that there is a certain degree of empowerment when working not only on the instrumental or emotional dimension, but when there is a combination of the two. Therefore, in order for a girl to acquire a certain degree of autonomy, she will also have to be provided with emotional well-being and take into account other social aspects, like gender norms (study 7), to achieve a favorable impact with regard to empowerment through mentoring (studies 10, 11 and 14). In this respect, it is worth noting the studies analyzed on educational and professional mentoring, in which young women's self-esteem was improved. The subjects in these studies were more proactive in their decision-making, developed a stronger professional identity and feeling of belonging to the organization and set more ambitious objectives, even though they worked in very male environments (studies 6,7 and 8). Finally, another relevant aspect is that through these programs the participants' feelings of loneliness and isolation were reduced, and this contributed to their self-esteem positively and to improving their social capital (study 5, 6, 7 and 8).

- Empowerment in the face of sexual and gender violence. One last aspect linked to the empowerment of girls, which emerges in four of the studies found, is the gender and sexual violence suffered by young women in intimate and sexual relationships (studies 13,12 and 18). On the one hand, the mentoring relationship created a space of trust where the young women, some of them married, could talk about sexuality and sexual rights without fear of retaliation by their partner or the community (study 13). This participation becomes important for girls to break the gender violence dynamics that seek social control and the isolation of women from public life.

In some cases, counselling may also have undesired results. Study 18 provided a critical analysis of the discourse on sexuality transmitted by mentors on the mentoring programs in relation to three subjects: the first was the mentors' assessment of the appropriate age for the girls' sexuality, the second was the mentors' opinion on the young women's level of sexual freedom based on moralistic discourses, and the third was reducing the young women to victims with no capacity of agency or negotiation regarding their sexuality. Therefore, this study and others (3,9 and 21) show how regulatory discourses on desirable sexual behavior for a young girl are made from an adult-gendered-biased.

\subsubsection{The participants}

Research on mentoring programs seeks to determine how the programs affect participants, including the mentor and the mentee (studies 11, 15 and 16). In the studies analyzed, the mentor is usually an older adult than the mentee, a man or a woman who is expected to be able to provide support, accompani- 
ment and/or training to someone with less experience or fewer personal and social resources (study 14). The mentee is a young woman, aged between 15 and 30, who pursues goals to improve some aspect of her life.

Although the interventions on the mentoring programs analyzed are intended to eradicate gender inequality, they may also reproduce other unconscious "power" dynamics that generate a disempowering internal mechanism in the relationship (study 21). Consequently, these power dynamics can nullify the desired agency capacity necessary for empowering the girl (study 3 ). In this sense, these authors proposed that work be carried out on the mentoring bond based on the idea of the sisterfriend. This framework emphasized the need to democratize and horizontalize mentoring couples (study 9).

Finally, the RHI-M (Relational Health Index-Mentor) index proposed by Liang et al. (2002) (study 19) provided information on the social and psychological effects the mentor has on the mentee. Hence, this work proposed the need to train in instrumental competences but also in those ethical, social and emotional aspects, as part of a person's development and therefore of the mentoring relationship.

\section{Future directions: Implications for research and socio-educational practice}

This article highlights the need to introduce the feminist perspective in mentoring programs for girls at risk of social exclusion.

Despite there being over 201,000 studies on "youth mentoring" in the databases, this scoping review has only been able to include three that define themselves as research on feminist mentoring. Therefore, far more feminist scientific production in mentoring for girls is necessary in order to provide interventions that are coherent with the reality of their everyday lives.

Mentoring programs for young women are designed, directly or indirectly, on the basis that gender is understood as a vector of social exclusion. Consequently, it is essential that mentoring also includes competencies and knowledge related to gender equality in the direct and indirect learning that girls experience on mentoring programs.

Mentoring programs built from a feminist framework aim to understand, in a polyhedral way, the complexity of the positions that young women occupy in the different contexts of mentoring programs. These are programs that could be classified as femtoring or as feminist and intercultural mentoring programs, sometimes with a clear influence of intersectional and/or decolonialism feminisms.

As proposed by femtoring and other works reviewed, empowerment in mentoring for young women should be understood as a joint process that concerns both the mentor and the mentee, and not only the latter. Thus, empowerment in youth mentoring must abandon the precepts of social work that conceive the professional/adult as the person who empowers the young person. Likewise, femtoring attempts to reconnect what Brown \& Gilligan 
(1993) understand as key for empowerment - that is, their own voice, psyche and body.

The characteristics of the qualitative methodology allow us to determine the extent to which girls acquire competences related to equality and empowerment, because it is a methodology that brings us closer to the internal processes of the mentoring relationship.

\section{Bibliographical references}

Arksey, H. \& O’Malley, L. (2005). Scoping studies: toward a methodological framework. International journal of social research methodology, 8(1), 19-32. <https://doi.org/10.1080/1364557032000119616>

Bankar, S.; Collumbien, M.; Das, M.; Verma, R. K.; Cislaghi, B. \& Heise, L. (2018). Contesting restrictive mobility norms among female mentors implementing a sport based program for young girls in a Mumbai slum. BMC public health, 18(1), 471 <https://doi.org/10.1186/s12889-018-5347-3>

Bay-Cheng, L.Y.; Lewis, A. E.; Stewart, A. J. \& Malley, J. E. (2006). Disciplining "Girl Talk" The Paradox of Empowerment in a Feminist Mentorship Program. Journal of Human Behavior in the Social Environment, 13(2), 73-92. <https://doi.org/10.1300/J137v13n02_05>

Benishek, L. A.; Bieschke, K. J.; Park, J. \& Slattery, S. M. (2004). A multicultural feminist model of mentoring. Journal of Multicultural Counseling and Development, 32, 428.

Bogat, G. A.; Liang, B. \& Rigol-Dahn, R. M. (2008). Stages of mentoring: An analysis of an intervention for pregnant and parenting adolescents. Child and Adolescent Social Work Journal, 25(4), 325-341. <https://doi.org/10.1007/s10560-008-0130-4>

Brown, R. N. (2006). Mentoring on the Borderlands: Creating empowering connections between adolescent girls and young women volunteers. Human Architecture: Journal of the Sociology of Self-Knowledge, 4(3), 13.

Brown, L. M. \& Gilligan, C. (1993). Meeting at the crossroads: Women's psychology and girls' development. Feminism \& Psychology, 3(1), 11-35.

Clutterbuck, D.; Poulsen, K. M. \& Kochan, F. (2012). Developing successful diversity mentoring programs: An international casebook. United Kingdom: McGraw-Hill Education.

Dubois, D. L. \& Karcher, M. J. (Eds.) (2013). Handbook of youth mentoring. California: Sage Publications.

EMPOWERING CARE (2013). Empowering girls in residential care against violence against women. Daphne toolkit (UE) JUST/2012/DAP/AG/3078. Retrieved September 13, 2019, from <https://ec.europa.eu/justice/grants/results/daphnetoolkit/content/empowering-care-empowering-girls-residential-care-againstviolence-against-women-0_en>.

Eurostat (European Statistics) (2016). Recorded offences by offence category-police data [Dataset]. Retrieved September 13, 2019, from <http://appsso.eurostat.ec. europa.eu/nui/show.do?query=BOOKMARK_DS-559176_QID_1727C2DE_ UID_-3F171EB0\&layout=ICCS,L,X,0;UNIT,L,X, 1;GEO,L,Y,0; $\bar{T}$ IME,C,Z,0;I NDICATORS, C,Z, 1; \&zSelection=DS-559176TIME,2015;DS- 
559176INDICATORS,OBS_FLAG;\&rankName1=INDICATORS_1_2_1_2\&rankName2=TIME_1_0_0_0\&rankName3=ICCS_1_2_0_08rankName 4=UNIT_1_2_1_0\&rankName5=GEO_1_2_0_1\&rStp=\&cStp=\&rDCh=\&cD $\mathrm{Ch}=\& \mathrm{rDM}=$ true $\& \mathrm{cDM}=$ true $\&$ footnes=false\&empty=false\&wai=false\&time mode=ROLLING\&time_most_recent=true\&lang=EN\&cfo= $\% 23 \% 23 \% 23 \%$ $2 \mathrm{C} \% 23 \% 23 \% 23 . \% 23 \% 23 \% 23>$.

- (2017). Structure of earnings survey: monthly earnings [Dataset]. Retrieved September 13, 2019, from <http://appsso.eurostat.ec.europa.eu/nui/submit ViewTableAction.do>.

- (2018). People at risk of poverty or social exclusion by age and sex [Dataset]. Retrieved September 13, 2019, from <http://appsso.eurostat.ec.europa.eu/nui/ submitViewTableAction.do>.

Falb, K. L.; Tanner, S.; Ward, L.; Erksine, D.; Noble, E.; Assazenew, A.; BaKmere, T.; Graybill, E.; Lowry, C.; Maligna, A. N.; Poulton, C.; Robinette, K.; SOMMER, M. \& STARK, L. (2016). Creating opportunities through mentorship, parental involvement, and safe spaces (COMPASS) program: multi-country study protocol to protect girls from violence in humanitarian settings. BMC public health, 16(1), 231. <https://doi.org/10.1186/s12889-016-2894-3>

Fassinger, R. E. \& Hensler-Mcginnis, N. F. (2005). Multicultural Feminist Mentoring as Individual and Small-Group Pedagogy. In C. Z. EnNS, \& A. L. SinACORE (Eds.). Teaching and social justice: Integrating multicultural and feminist theories in the classroom (pp. 143-161). Washington, DC, US: American Psychological Association. $<$ https://doi.org/10.1037/10929-009>

Greeson, J. K. \& Bowen, N. K. (2008). "She holds my hand" The experiences of foster youth with their natural mentors. Children and Youth Services Review, 30(10), 1178-1188. <https://doi.org/10.1016/j.childyouth.2008.03.003>

Hernandez, P. R.; Bloodhart, B.; Barnes, R. T.; Adams, A. S.; Clinton, S. M.; Pollack, I.; Godfrey, E.; Burt, M. \& Fischer, E. V. (2017). Promoting professional identity, motivation, and persistence: Benefits of an informal mentoring program for female undergraduate students. Plos one, 12(11), e0187531. $<$ https://doi.org/10.1371/journal.pone.0187531>

Kalpazidou Schmidt, E. \& Faber, S. T. (2016). Benefits of peer mentoring to mentors, female mentees and higher education institutions. Mentoring \& Tutoring: Partnership in Learning, 24(2), 137-157. $<$ https://doi.org/10.1080/13611267.2016.1170560>

Kirst, M.; Lazgare, L. P.; Zhang, Y. J. \& O'Campo, P. (2015). The effects of social capital and neighborhood characteristics on intimate partner violence: A consideration of social resources and risks. American Journal of Community Psychology, 55(3-4), 314-325. <https://doi.org/10.1007/s10464-015-9716-0>

Klaw, E. L.; Rhodes, J. E. \& Fitzgerald, L. F. (2003). Natural mentors in the lives of African American adolescent mothers: Tracking relationships over time. Journal of Youth and Adolescence, 32(3), 223-232. <https://doi.org/10.1023/A:1022551721565>

Larsson, M.; Pettersson, C.; Eriksson, C. \& Skoog, T. (2016). Initial motives and organizational context enabling female mentors' engagement in formal men- 
toring-A qualitative study from the mentors' perspective. Children and Youth Services Review, 71, 17-26.

<https://doi.org/10.1016/j.childyouth.2016.10.026>

Larsson, M.; Pettersson, C.; Skoog, T. \& Eriksson, С. (2016). Enabling relationship formation, development, and closure in a one-year female mentoring program at a non-governmental organization: a mixed-method study. BMC public health, 16(1), 179. $<$ https://doi.org/10.1186/s12889-016-2850-2>

Levine, R. B.; Mechaber, H. F.; Reddy, S. T.; Cayea, D. \& Harrison, R. A. (2013). "A good career choice for women": female medical students' mentoring experiences: a multi-institutional qualitative study. Academic Medicine, 88(4), 527-534. <https://doi.org/10.1097/ACM.0b013e31828578bb>

Leck, J. D.; Elliott, C. \& Rockwell, B. (2012). E-Mentoring women: Lessons learned from a pilot program. Journal of Diversity Management (Online), 7(2), 83. $<$ https://doi.org/10.19030/jdm.v7i2.7476>

Liang, B.; Bogat, A. \& Duffy, N. (2013). Gender in mentoring relationships. In Handbook of Youth Mentoring (pp. 159-174). Thousand Oaks, CA: Sage. $<$ https://doi.org/10.4135/9781412996907.n11>

Liang, B.; Tracy, A. J.; Taylor, C. A. \& Williams, L. M. (2002). Mentoring college-age women: A relational approach. American journal of community psychology, 30(2), 271-288. <https://doi.org/10.1023/A:1014637112531>

Lindsay-Dennis, L.; Cummings, L. \& McClendon, S. C. (2011). Mentors' reflections on developing a culturally responsive mentoring initiative for urban African American girls. Black Women, Gender + Families, 5(2), 66-92. $<$ https://doi.org/10.5406/blacwomegendfami.5.2.0066>

McGill, J.; Adler-Baeder, F.; Sollie, D. L. \& Kerpelman, J. L. (2015). Exploring the experiences of female emerging adult mentors: Building a conceptual model. Journal of Adolescent Research, 30(5), 538-564. <https://doi.org/10.1177/0743558414538317>

Mezey, G.; Meyer, D.; Robinson, F.; Bonell, C.; Campbell, R.; Gillard, S.; Jordan, P.; Mantovani, N.; Wellings, K. \& White, S. (2015). Developing and piloting a peer mentoring intervention to reduce teenage pregnancy in lookedafter children and care leavers: an exploratory randomised controlled trial. Health Technology Assessment, 19(85). $<$ https://doi.org/10.3310/hta19850>

Newton, J. A.; Harris, T. O.; Hubbard, K. \& Craig, T. K. J. (2017). Mentoring During the Transition from Care to Prevent Depression: Care Leavers' Perspectives. Practice, 29(5), 317-330. $<$ https://doi.org/10.1080/09503153.2017.1329414>

ObSERVATORI IQ (2016). Población activa, según el sexo y nivel formativo superado. Cataluña, 2017. Retrieved September 13, 2019, from <http://iqobservatori. org/poblacio-activa-segons-sexe-i-nivell-de-formacio-assolit-catalunya2011-2016>.

OBSERVATORIo Noctámbul@s (2017). $4^{0}$ Informe anual 2016-2017. Observatorio sobre la relación entre el consumo de drogas y las violencias sexuales en contextos de ocio nocturno. Retrieved September 13, 2019, from <https://www.drogasgenero. info/4o-informe-noctambulas-2016-17-ya-on-line/>. 
Phipps, A. (2007). Re-inscribing gender binaries: Deconstructing the dominant discourse around women's equality in science, engineering, and technology. The sociological review, 55(4), 768-787. <https://doi.org/10.1111/j.1467-954X.2007.00744.x>

Rhodes, J. E. (2005). A model of youth mentoring. In Dubois, D. L., \& Karcher, M. J. (Eds.). Handbook of youth mentoring (pp. 30-43). Thousand Oaks, CA: Sage. <http://dx.doi.org/10.4135/9781412976664.n3>

Russell, L.; Alsop, R.; Bradshaw, L.; Clisby, S. \& Smith, K. (2016). The state of girls' rights in the UK. London: Plan international UK.

Sanghera, G. S. \& Thapar-Bjorkert, S. (2017). Transnationalism, social capital and gender-young Pakistani Muslim women in Bradford, UK. Migration Letters. $<$ https://doi.org/10.33182/ml.v14i1.318>

Segato, R. (2003). Las Estructuras Elementales de la Violencia. Ensayos sobre género entre la Antropología, el Psicoanálisis y los DD. HH. Buenos Aires, Argentina: Prometeo 3010, Universidad Nacional de Quilmes.

Spencer, R. \& Liang, B. (2009). "She gives me a break from the world": Formal youth mentoring relationships between adolescent girls and adult women. The Journal of Primary Prevention, 30(2), 109-130. <https://doi.org/10.1007/s10935-009-0172-1>

Tortolani, C. C. (2011). StrongLinks: a mixed methods study exploring urban ethnic girl' experiences, connections and relationships (PhD). Universidad de Northeaster, Boston.

Verge, T.; Ferrer-Fons, M. \& GonzÁlez, M. J. (2018). Resistance to mainstreaming gender into the higher education curriculum. European Journal of Women's Studies, 25(1), 86-101. <https://doi.org/10.1177/1350506816688237>

World Health Organization (2017). Rights, results and resilience: Rapid implementation of the 2030 Agenda. Retrieved from <https://annualreport.unwomen.org/ en/2017>. 